\title{
Vertical greenery systems: from plants to trees with self-growing interconnections
}

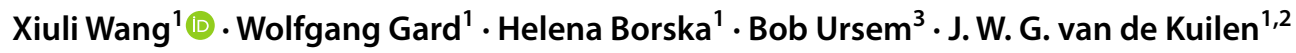

Received: 11 October 2019 / Published online: 9 August 2020

(c) The Author(s) 2020

\begin{abstract}
The integration of buildings into vegetation has become a necessity in many metropolitan areas of the world today. It expands the potential of vertical and horizontal, exterior and interior, exposed and enclosed spaces in a building that can be used to accommodate plants. Green infrastructures have benefits both on urban and building scales. They can be categorized into green roofs and vertical greenery systems that can be divided further into green façade, green wall, green terraces, elevated forest and vertical forest. There are many design and planting considerations for architects, structural engineers and botanists when using living architectures to mimic natural systems, such as plant characteristics and environmental conditions. Plants used for vertical greenery are more likely to be hardwood species to adjust solar radiation during cooling and heating periods, as well as for aesthetic pleasure. Take Bosco Verticale, which is located in Milan, as an example to look into engineering methods when trees grow on balconies of high-rise buildings. It can be concluded that planting restraint safety systems and regular maintenance are necessary for the tree growth in the sky. However, the change in growing conditions causes various problems such as stability and irregular growth of trees. Instead of using steel cables and cages to prevent trees from falling off in the sky, the concept of self-growing connections is proposed to act as natural bracings and provide the stability for vertical forests. This paper is meant to generate awareness of the possibilities of the vertical integration of trees into buildings, show application considerations, and inspire future developments.
\end{abstract}

\section{Introduction}

Cities are getting bigger and denser while buildings are getting bigger and taller. There is a growing significance of environmental issues such as urban island effects and reduction in energy consumption, which are relevant to dense urbanization. While high-rise buildings as a typology have evolved to become predominant nowadays, there are several challenges to meet. One is that buildings should be

This article will be part of our Special Issue dedicated to ISCHP 2019.

Xiuli Wang

X.Wang-16@tudelft.nl

1 Biobased Structures and Materials, Faculty of Civil Engineering and Geosciences, Delft University of Technology, Delft, The Netherlands

2 Chair of Wood Technology, Technical University of Munich, Munich, Germany

3 Department of Biotechnology, Faculty of Applied Sciences, Botanic Garden Delft University of Technology, Delft, The Netherlands more in tune with their locations in terms of both sustainability and design (Wood 2008). Another challenge is that buildings should minimize the use of energy, reduce waste, while at the same time provide increased comfort, a healthy environment and safety for people who live and work in them (Sheweka and Magdy 2011). With increasing building height, it is challenging to provide a high-quality living environment with natural components, but vegetation is needed from a social and environmental perspective, giving relief to occupants and citizens.

Vegetation plays an important role in its special function as energy balance and improves human health in urban areas as air quality improves and temperature is better controlled. The benefits of vegetation in buildings are similar to ordinary vegetation in cities. It has become an important new construction principle to increase the livability and sustainability of modern buildings both outdoor and indoor (Feng and Hewage 2014). Positive climate effects can be created by combining green cover on walls, roofs, and in open spaces in the vicinity of buildings (Wilmers 1990). Indoor plants can provide comfort by means of purification (Wolverton and Wolverton 1993), humidification and psychological 
relaxation (Raji et al. 2015), and indoor greening technology such as indoor vertical green walls have proved to be an effective way to improve indoor air quality (Wang et al. 2016). Comparing outdoor plants with blinds in buildings, plants create more effective shading performance than blinds, which should be considered as a way of construction with building envelope (Stec et al. 2005).

In densely populated regions, where green areas are scarce and open ground space is limited, the concept of integrating nature into high-rise buildings represents an innovative and sustainable opportunity for green infrastructure in cities (Medl et al. 2017). Greening technology can protect building façades, which are under permanent environmental influences such as sun and rain, and which may damage the façades and reduce their service life (Köhler 2008). Roofs of buildings are also suitable spaces to accommodate vegetation. At the same time, greening of walls of high-rise buildings can also be feasible since the ratio between surface area of walls and roofs may reach the value of 20 (Pérez et al. 2014). Many countries in the world, such as the USA (Susorova et al. 2013), Italy (Giacomello 2015) and Singapore (Yok 2013) have shown great interests in green infrastructures. The technologies of green infrastructures extend the potential of horizontal, vertical areas in a building that can accommodate plants, not to mention exterior and interior spaces (Tan et al. 2014).

This study is part of a comprehensive research project on Vertical Forest Engineering (VFE) and includes an overview of current developments and state-of-the-art technologies for vertical greenery systems. An identification of vertical greenery options is made, and a classification of building greenery systems is proposed. Recommendations are given for design considerations and planting strategies that should be studied in depth during the design phase of buildings and green spaces. Based on the principle of 'vertical forests', an innovative concept of self-growing connections, connecting multiple trees on vertical façades is presented. The proposed system provides both stability and reliability to trees in a vertical forest. Additionally, it might reduce unwanted windinduced tree deformations.

\section{Green infrastructure}

\subsection{Classification}

Greenery can be integrated into buildings in many forms including horizontal and vertical, exterior and interior spaces. Green infrastructure can be considered as comprising all natural, semi-natural and artificial networks of multifunctional ecological systems within, around and between urban areas, at all spatial scales (Tzoulas et al. 2007). Because of the diversity of disciplines, application contexts, methods, terminologies, purposes and valuation criteria, there is no consensus on a comprehensive classification for green infrastructure (Koc et al. 2017).

In this study, green infrastructures are organized into two main categories, which are horizontal greenery and vertical greenery systems. For horizontal greenery, it includes green roofs and elevated forests, while vertical greenery systems include green façades, green walls, green terraces and vertical forests.

\subsection{Horizontal greenery}

Green roofs are one of the earliest forms of green infrastructures. They can be defined as roofs with a vegetated surface and substrate which can be divided into intensive and extensive green roofs depending on substrate depths, roof dimension and intensity of use. It can provide ecosystem services in urban areas, including improved storm-water management, better regulation of building temperatures, increased sound insulation (Dunnett and Kingsbury 2008), reduced urban heat-island effects (Besir and Cuce 2018), and increased urban wildlife habitat (Oberndorfer et al. 2007). Its relatively lightweight nature allows for its use on many roofs without the need for structural strengthening, and it has seen a surge in installations worldwide (Tan et al. 2014). Another form of horizontal greenery is the elevated forest. This class of greenery refers to trees growing in sheltered horizontal spaces, forming a kind of forest in the sky. While horizontal spaces provide accommodations for plants, vertical spaces offer different possibilities. Apart from the development on the horizontal surfaces, vertical spaces provide opportunities to integrate vegetation into buildings.

\subsection{Vertical greenery systems}

Vertical greenery systems can be defined as structures that spread vegetation that may or may not be attached to a building façade or to an interior wall (Pérez-Urrestarazu et al. 2015a, b). It is also called vertical garden (Peck et al. 1999), green wall, vertical green and sky-rise greenery (Blanc and Lalot 2008; Tan et al. 2014; Timur and Karaca 2013). There are four main components in vertical greenery systems: plants, planting media such as substrate and containers, supporting systems which can hold plants, and irrigation systems (Wood et al. 2014).

According to the strategies under development for vertical greenery systems, they can be categorized as green façade, green wall, green terraces and vertical forest (Marugg 2018; Ottelé 2011; Serra et al. 2017; Sheweka and Magdy 2011). However, there are some differences between the definitions in various fields. For a more common understanding, within this vertical forest engineering study, characteristics and definitions of various types of vertical greenery systems have 
been formulated according to the application and location as can be seen from Fig. 1 and Table 1 .

- Green façade refers to vegetation rooted on the ground, which makes use of either the wall itself for climbing (traditional direct systems) or independent supporting systems, such as trellis, wires, cables or meshes (doubleskin indirect system) affixed to walls (Fernández-Cañero et al. 2018).

- Green wall has been made using geotextile, pots, panels, boxes or modular nets, where pre-cultivated vegetation has been planted and subsequently suspended and fixed to a building structure (Bartesaghi Koc et al. 2017). Green walls demand more complex constructions and imply higher installation and maintenance costs in comparison to green façades (Dunnett and Kingsbury 2008).

- Green terraces are defined as plants growing on the horizontal terraces continuously along the façade, which are built on different heights and levels.

- Vertical forest uses cantilevered balconies around the building envelope, acting as an accommodation for trees to grow, where the group of trees is formed into vertical forests.

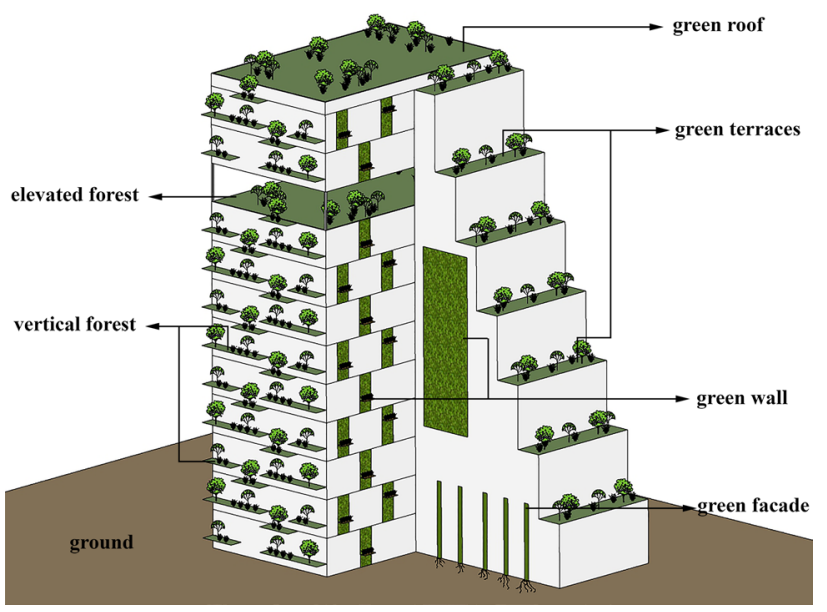

Fig. 1 Classification of green infrastructure
Vertical forest engineering (VFE) is a relatively new field for architects, botanists and structural engineers. It requires deeper studies with respect to plant and tree species, nutrition and growth conditions (e.g. root system development in a confined soil space, sunlight, prevailing winds, nearby facades) as well as engineering aspects with regard to horizontal loads (wind, earthquakes), tree stability. An important aspect also is how these parameters develop in the course of time.

\section{Benefits of vertical greenery}

\subsection{Environmental benefits}

Integrating nature into buildings has become a necessity in densely populated areas. It is widely acknowledged that a proper arrangement of plants and trees around buildings not only has positive psychological effects but also improves microclimatic conditions around these buildings (Hoyano 1988).

Vegetation has a capacity of evapotranspiration, which can decrease the ambient temperature around plants. With higher wind speeds, evapotranspiration of vegetation increases too. This can basically be explained by decreasing building surface temperatures. Therefore, for high-rise buildings, in order to get lower temperatures on the building façades, an effective way is to arrange the plants around the envelope wisely by increasing the evapotranspiration of plants around them (Takakura et al. 2000).

\subsubsection{Shading effect}

Vegetation can also provide shade to buildings, protect them from direct solar radiation and at the same time create a homogenous microclimatic interphase between plants and building surfaces. By changing the energy performance of buildings, energy saving is one of multiple benefits that vertical forest systems can offer to high-rise buildings (Coma et al. 2017; Raji et al. 2015). The leaf area index is an important factor relevant to this energy saving through

Table 1 Identification and classification

\begin{tabular}{lll}
\hline Typologies & Plants & Characteristics \\
\hline Green façade & Climbing plants & $\begin{array}{c}\text { Plants rooted on the ground and climbing on the façades of the building by themselves or } \\
\text { through the support of other structures }\end{array}$ \\
Green wall & $\begin{array}{l}\text { Modular plants or plants with } \\
\text { hanging-down branches } \\
\text { Green terraces }\end{array}$ & $\begin{array}{l}\text { Short, medium and tall plants } \\
\text { façades for hanging and placing plants }\end{array}$ \\
$\begin{array}{lll}\text { Growing in the planting media which is located on horizontal terraces at different levels con- } \\
\text { tinuously along the façade }\end{array}$ \\
Vertical forest & Trees & $\begin{array}{l}\text { Trees growing in sheltered horizontal (open) spaces } \\
\text { Trees or groups of trees growing on cantilevering balconies }\end{array}$ \\
\hline
\end{tabular}


evapotranspiration and solar shading. Wong et al. (2009) conducted experiments on vertical greenery systems and found that shading coefficient has a linear correlation with the leaf area index. However, the shading effect may have different effects depending on cooling and heating seasons. In summer seasons, plant canopies strategically integrated into building façades may act as sun screen devices to filter solar radiation (Ip et al. 2010). If using evergreen plants for vertical forest systems, plants may mainly positively influence the building energy consumption by plant coverage during both heating and cooling times. Whereas for deciduous plants in winter, they may have minor effect on the microclimate between building surfaces and plants. During the summer months, vertical greenery systems would have the twofold effect of reducing incoming solar energy into the building through shading and reducing heat flow (Wong et al. 2010a). Studies have shown that with proper design and selection strategies of plants in vertical greenery systems, the energy performance of high-rise buildings can be improved (Marugg 2018; Raji et al. 2015). In other words, to make full use of the energy saving advantages of vertical greenery systems, the planting strategy requires careful consideration when vertical greenery systems are designed.

\subsubsection{Thermal insulation}

In vertical greenery systems, the use of climbing plants and other plant species as a part of building enclosures has been shown to improve thermal performance of facades during summer in Chicago (Susorova et al. 2014). By evapotranspiration of vegetation, Besir and Cuce (2018) found that the external surface temperature of vertical greenery systems reduces in the range of $3.7-11.3^{\circ} \mathrm{C}$, while increasing the percentage of plant foliage in the system between 13 and 54\%. Reductions in external surface temperatures of the building façades were considerable in warm temperate climate, ranging from 12 to $20.8{ }^{\circ} \mathrm{C}$ in the summer period and 5 to $16^{\circ} \mathrm{C}$ in autumn (Pérez et al. 2014). Cuce (2017) studied green walls with about $10 \mathrm{~cm}$ thick Hedera helix in sunny sky conditions of temperate climates like Nottingham in the UK. Results revealed that an average reduction of $2.5^{\circ} \mathrm{C}$ in internal wall temperature could be achieved. A case study in Hong Kong found that a vertical greenery wall saved as much as $16 \%$ of the electricity consumption for air-conditioning in August and September with typical daily temperatures of $25-30{ }^{\circ} \mathrm{C}$ (Pan and Chu 2016). For a tropical climate, Wong et al. (2010a) found a reduction in the surface temperature of building façades by more than $11^{\circ} \mathrm{C}$ in the wall surface temperature on clear days. Mazzali et al. (2013) conducted experiments to investigate the energy behavior on buildings in a Mediterranean temperate climate. The results showed that during sunny days, differences in temperature between the bare wall and the covered wall range from 12 to $20{ }^{\circ} \mathrm{C}$. In different light conditions, the leaf orientation varies, and the leaves of plants are in motion to optimize the growth conditions. Based on terrestrial LiDAR, a movement parameterization of leaves can be quantified (Herrero-Huerta et al. 2018). The thermal benefits of vertical forest systems highly depend on vegetation intensity and its orientation with respect to the microclimate condition between building surfaces and plants.

\subsubsection{Other environmental benefits}

Apart from the previous aspects, vertical forest systems can also influence building acoustic performance (Wong et al. 2010b). Furthermore, urban vegetation has been shown to improve the air quality by continuous air flow (Dunnett and Kingsbury 2008; Perini et al. 2011) and depositing dust (Perini et al. 2017). The air quality improvement due to vegetation is related to the absorption of fine dust particles and the uptake of gaseous pollutants (Perini et al. 2013).

Vertical forest systems are also important especially in dense urban areas as they create a habitat for urban plants and native wildlife (birds, insects) by supporting biodiversity (Francis and Lorimer 2011; Perini et al. 2013). However, biodiversity in sky gardens may not be as high as that at ground level, because of the thinner soil layer, and more severe living environment such as higher temperature and stronger winds (Tian and Jim 2011). On the other hand, vertical green systems create green spaces in urban areas that were previously non-existent, allowing regaining some of the biodiversity that got lost during the urbanization stage.

\subsection{Social benefits}

Plants give beauty unstintingly and remain steadfast. It is known that people are more likely to suffer from a range of medical and mental health problems if they are living in areas without 'green' components. By providing a more comfortable living and working environment, it has also been proved that visual and physical contacts with plants can result in direct health benefits. Plants can generate restorative effects leading to decreased stress and improved work productivity (Sheweka and Magdy 2011). By integrating vegetation into high-rise buildings in urban areas, for instance trees growing on balconies, they can act as wind barrier and create a more comfortable environment for human wellbeing.

\subsection{Economic benefits}

Vertical forest systems can have positive benefits on building costs mainly by optimizing the energy performance during heating and cooling months of high-rise buildings. Energy loss is a crucial issue for energy performance and depends 
on building age and type, climate, the materials used in the building envelop, but also occupant behavior.

As an example, in the wet and cold climates in the Chinese province of Hunan, an energy saving rate of $18 \%$ was achieved during a heating experiment owing to the extra thermal insulation provided by the vertical greening system (Xing et al. 2019). For energy effectiveness, tree arrangements provide shade, in Hong Kong for instance, primarily for east and west walls, while it may provide wind protection from the prevailing winter winds direction, but this arrangement will vary depending on the geographical regions.

Because of a lack of technical information, experiences with maintenance, and professional information on locally available plants suitable for vertical forest systems, the application of vertical greenery is hindered. Similarly, the lack of awareness and proof of long-term economic benefits for building owners is considered a barrier.

Grants and subsidies for vertical forest systems can be considered for implementation, providing feedback to investors and potential building owners on possible benefits. Economic benefits may be obtained by lower heating costs, reduction in air and noise pollution, improvement in human wellbeing by being close to nature, which is a potential economic benefit. At the same time, negative influences also need to be understood as increased building and greenery maintenance costs during service life are expected, as well as higher upfront costs for construction as structural detailing for cantilevering balconies with soil-tree provisions.

In general, the main benefits connected to vertical greenery systems include environmental, economic, and social aspects on both building and urban scales. It also reflects that there is still a long way to go for the application of vertical forests to become daily practice.

\section{Planting strategies}

The species used in outdoor living walls vary to a great extent, depending on the location, the exposure to the sun and the height of the building (Pérez-Urrestarazu et al. $2015 \mathrm{a}, \mathrm{b})$. Factors that influence the vegetation growth are for example solar radiation and planting media when plants are used in vertical forest systems. Various plant physiological parameters such as leaf area index, average leaf dimension and leaf absorptivity can improve façade thermal performance (Susorova et al. 2013). For green façades, the number of useable plant species in the tropical areas is between 300 and 500 climber species. This is around 10 times more than in Europe (Köhler 2008). Selection of suitable plant species depends upon many factors such as climate conditions, building and plant orientation, wind effect, type of soil, characteristics of the container, requirements of water and nutrients, neighboring plant materials and the preferred visual effect. Native plant species should be given priority as they are well adapted to local weather conditions (Dahanayake and Chow 2015). Parameters for selecting the most suitable plants are given in Table 2.

By combining engineering technology and planting considerations for example, high-branching shade trees and low ground covers should be used to promote both shade and wind barriers in hot climates (McPherson et al. 1988). However, some trade-off discussions can also be identified. For instance, from a structural viewpoint it would be advantageous to have the volume of the substrate as small as possible for weight reduction, but for good plant growth it is necessary for them to have enough soil. Similarly, with higher elevation it might become more advantageous to use low plants, reducing the cooling capacity of vertical forests and avoiding tree distortion due to higher wind speeds.

\section{Vertical forests}

\subsection{Existing vertical forests}

The vertical forest as a new building concept has become quite popular recently, and there are many ongoing projects around the world. The characteristics of vertical forests include tree height, locations and spacing between the trees (both horizontal and vertical), distance between tree and the building envelope, canopy density and tree species. An appropriate selection of tree species and a proper placement of trees around buildings are important to improve benefits of trees on reducing building energy use. There are two cases

Table 2 Plant selection

\begin{tabular}{ll}
\hline Considerations & Parameters \\
\hline $\begin{array}{l}\text { Plant arrangement } \\
\text { Plant species }\end{array}$ & $\begin{array}{c}\text { Climatic consideration, orientation, wind effect, trees anchorage and fall off protection } \\
\text { Aesthetic appreciation, foliage, density, growth rate, tolerance of high height condition, } \\
\text { maintenance and repair activities }\end{array}$ \\
$\begin{array}{l}\text { Planting media } \\
\text { Maintenance and inspection }\end{array}$ & $\begin{array}{l}\text { Properties such as thickness, moisture content and density } \\
\text { Irrigation and drainage system }\end{array}$ \\
\hline
\end{tabular}


(Table 3) where vertical forests have been applied as a way of improving the quality of high-rise buildings (Blanc and Lalot 2008; Giacomello 2015). All the plants and tree species growing on balconies of Bosco Verticale were selected according to the context, the expected climate conditions, orientation, solar exposition and height, summarized in Table 3.

By observing the trees (Figs. 2, 3) in the Bosco Verticale, there are several aspects that need to be paid attention to:

- It is observed that the orientation of branches and density of foliage are different between two sides of the tree, but also vary around four sides of the building due to the possibility of either phototropism and thigmomorphogenesis of the trees or human intervention.

- If trees are subjected to directional horizontal forces, they will grow in a bent shape. This means that trees that are under the effect of a prevailing wind direction, for instance and in particular at building corners or at higher elevations, will not grow straight.

- In the course of time, trees in containers grow in size. Tree stability is one of the main concerns for the safe development of vertical forest systems.

\subsection{Stability of vertical forest}

The development of urbanization has a notable influence on the urban wind environment. The density and height of buildings in urban areas result in a complex wind field. Along the height of high-rise buildings, wind speed can be described using a power-law type equation. In the context of vertical forest environment, the wind load applied to trees varies according to the location of balconies. In

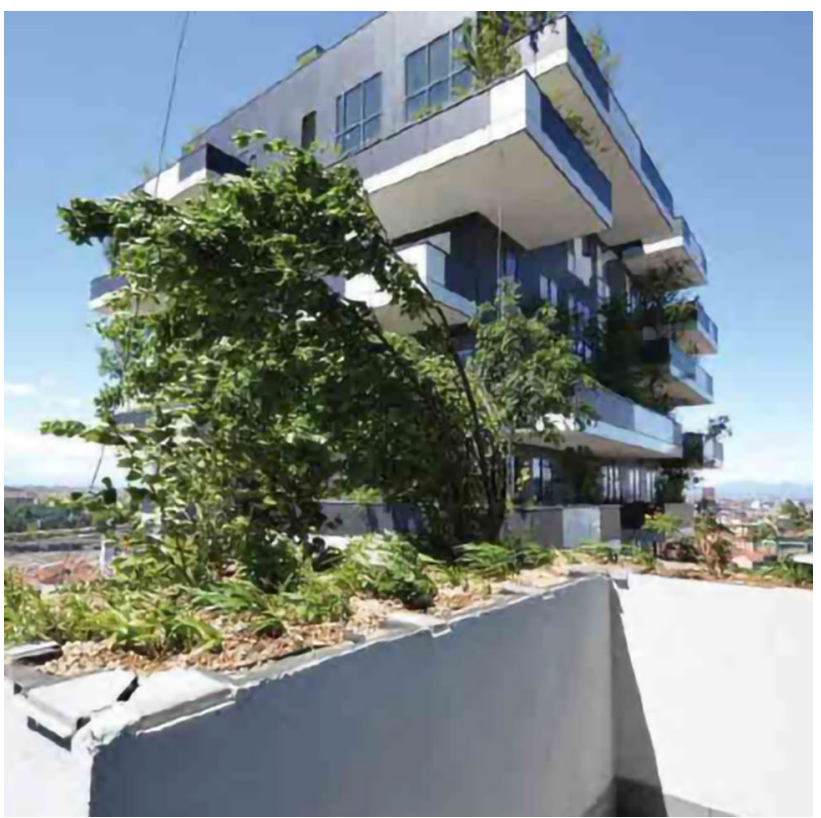

Fig. 2 Bent tree on the balconies in the corner under wind loads in Bosco Verticale (Giacomello 2015)

response to wind loads, tree stems tend to oscillate and leaves tend to flutter or even curl themselves (Niklas and Spatz 2012). As can be seen in Fig. 4, the tree will lose stability and have a chance to fall, when the applied bending moment $\left(M_{\text {wind }}\right)$ by wind load $\left(F_{\text {wind }}\right)$ exceeds the maximum resistive moment $\left(M_{r e s}\right)$. This resistive moment depends on the capacity of the stem and the root-soil system. The important factors of mechanical stability of trees are the modulus of rupture in bending of the stems and rotational anchorage capacity of the root system (Moore et al. 2018). They depend on tree species, their characteristics and growth conditions.
Table 3 Characteristics of vertical forest cases

\begin{tabular}{l|l|l|l}
\hline Cases & Pictures & Tree Species & Location and containers \\
\hline $\begin{array}{l}\text { Bosco Verticale } \\
\text { Milan,Italy } \\
\text { (Giacomello 2015) }\end{array}$ & $\begin{array}{l}\text { Acer campestre } \\
\text { Fagus sylvatica } \\
\text { Mafnolia stellata } \\
\text { Quercus ilex } \\
\text { Prunus subhirtella } \\
\text { Laburnum alpinum } \\
\text { (Tree heights are around 3, } \\
6 \text { and 9 meters.) }\end{array}$ & $\begin{array}{l}\text { Trees grow on balconies } \\
\text { around four sides of the } \\
\text { envelop, planted in } \\
\text { containers with the depth } \\
\text { of around one meter with } \\
\text { restraint systems to } \\
\text { prevent plants from falling } \\
\text { off. }\end{array}$ \\
$\begin{array}{l}\text { Newton Suites } \\
\text { (Blangapore and Lalot 2008) }\end{array}$ & $\begin{array}{l}\text { Plumeria L. } \\
\text { Trees grow on special } \\
\text { platforms on the north and } \\
\text { south sides with 900mm } \\
\text { deep containers. }\end{array}$ &
\end{tabular}




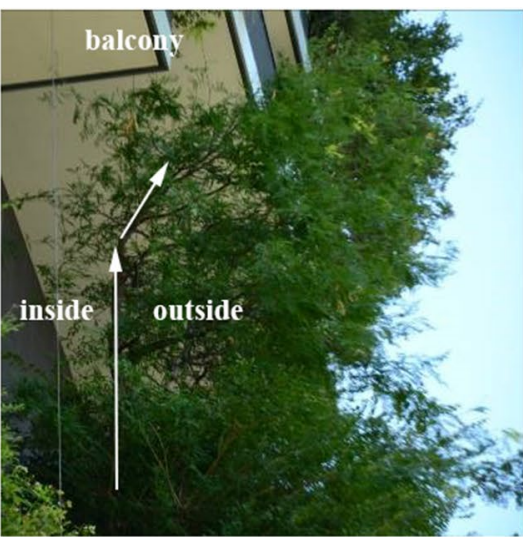

(a)

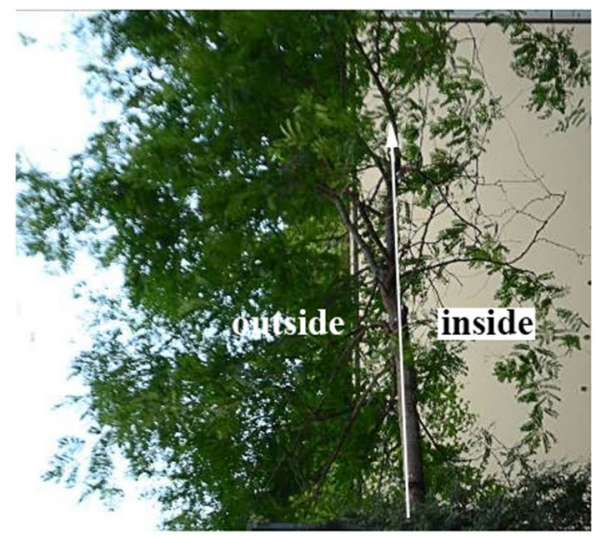

(b)

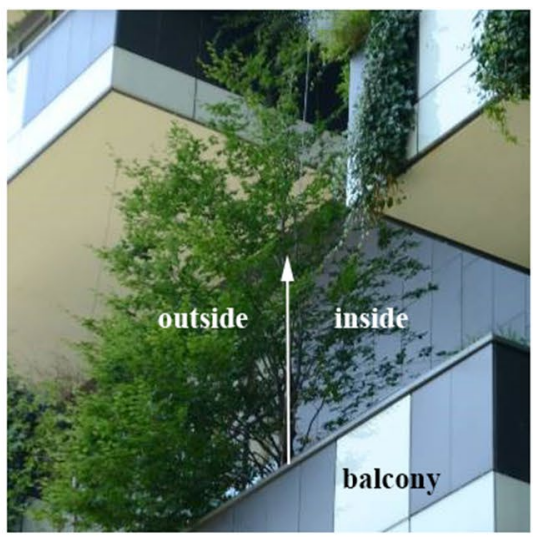

(c)

Fig. 3 Growth of trees in Bosco Verticale, a distorted stem and branches, $\mathbf{b}, \mathbf{c}$ trees with different dense foliage (inside near building surfaces and outside to the open air)

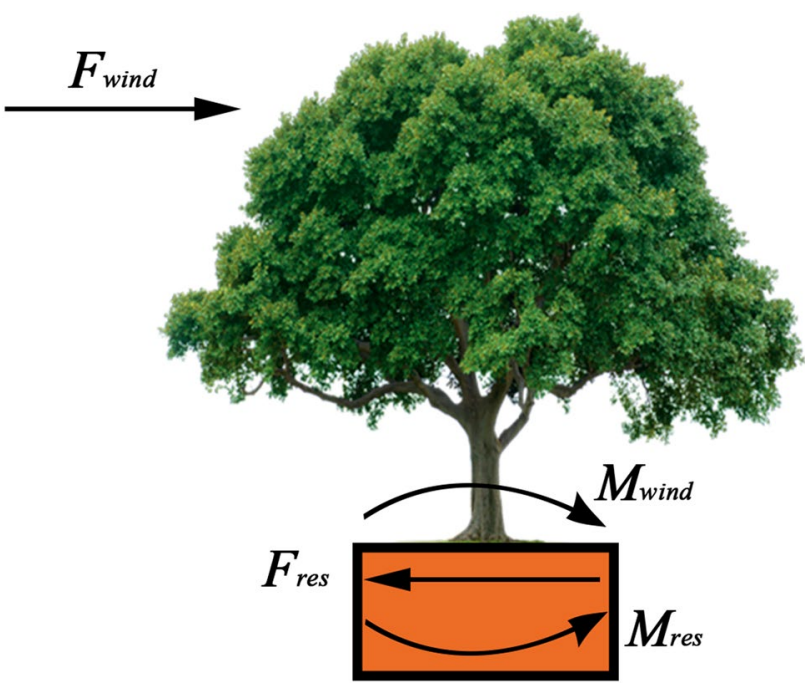

Fig. 4 The loading condition of a tree in a container $\left(F_{\text {wind }}\right.$ : wind loads, $F_{\text {res }}$ : resistance provided by stem, root and soil system, $M_{\text {wind }}$ : moment caused by wind loads, $M_{\text {res }}$ : resistive moment provided by stem, root and soil system.)

As for Bosco Verticale, to understand the aerodynamic and structural performance of whole buildings, a small-scale wind load assessment was carried out using a wind tunnel (Argentini et al. 2010). To ensure the security of trees at higher levels, full-scale trees were investigated to look into the interaction between wind and trees. Results show that at relatively high wind speeds, the load coefficients due to shape configuration of trees tend to be reduced, limiting the wind loads on trees (Aly et al. 2013). However, the root-soil system anchorage was not taken into consideration.

The structure of a tree can be simplified as a cantilevered beam with a tapered section that can provide stiffness to resist applied static and dynamic loads (Langre 2008).
However, because of the semi-rigid mechanical characteristics of the root system, the base cannot be considered as a rigid connection when analyzing the tree response in its entirety to external loads. The ability of the root-soil system to support the tree depends on root architecture, morphology, soil properties and growth conditions (Dupuy et al. 2007). In the vertical forest systems, a tree root system cannot develop freely due to the limited space in the containers, which may cause stability problems.

To ensure the stability of individual trees on balconies, in Bosco Verticale, artificial mechanical anchoring measures (Fig. 5) are installed to enhance the security of trees during extreme wind loads.

\subsection{Natural mechanical fixation system}

Instead of using steel support to hold trees for stability and safety, a natural mechanical fixation system with self-growing connections between multiple trees (Figs. 6, 7) is proposed to act as a possible way to provide sufficient stability and resistance in horizontal and vertical directions. The use of trees as engineering elements is possible for tree houses, where they act as a support structure (Nelson et al. 1994; Nuijten 2011), but trees can also be guided to grow into a natural structure. Within the framework of a building with nature program, a self-growing tree structure (Fig. 6) has been created at TU Delft. The structure is a study object in the Botanical Garden and has been growing for the last 9 years. The trees are planted in such a way that young branches can be tied together at an early stage. Trees are able to fuse and form self-growing connections (Fig. 7) to be a structural entity by itself. The trees are structured in such a way that they will be able to support a look-out platform within a couple of years, which is currently supported by a temporary structure. The nodes are the connections in 

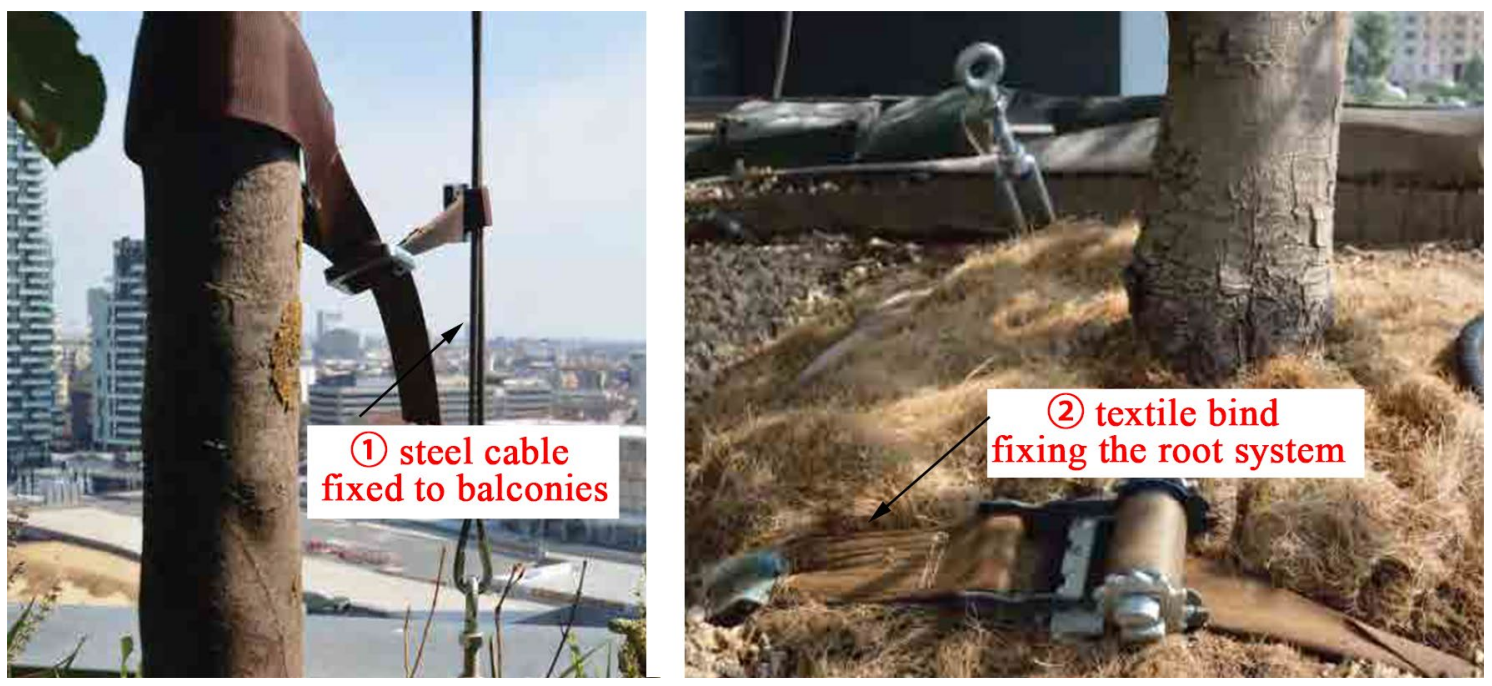

Fig. 5 Artificial mechanical anchoring of trees on balconies in Bosco Verticale (Giacomello 2015)

Fig. 6 Self growing structures, a design concept of self-growing structures (dots represent locations of self-growing connections), b existing self-growing structures in the Botanical Garden at TU Delft

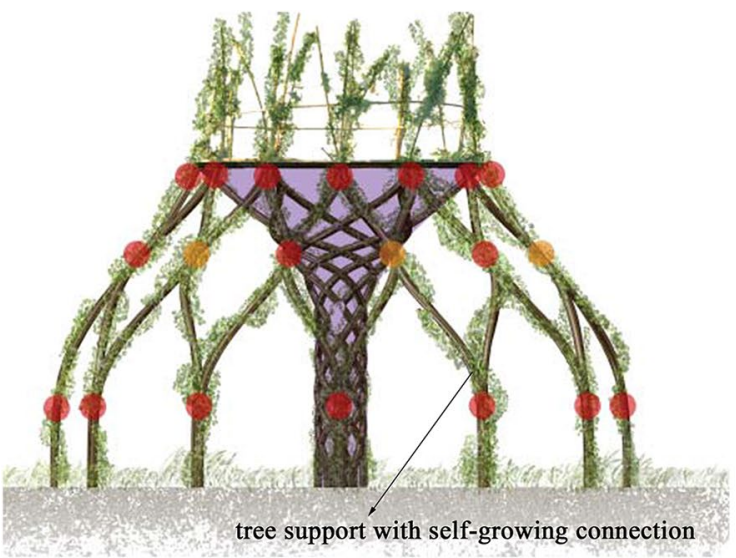

(a)

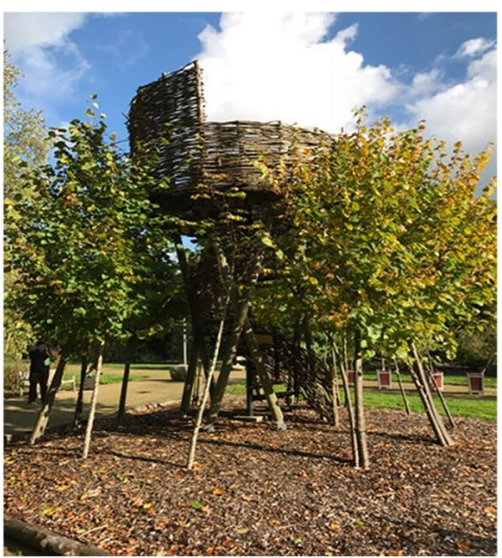

(b)
Fig. 7 Self-growing connections, a crosswise self-growing connection, b parallel-surface self-growing connection

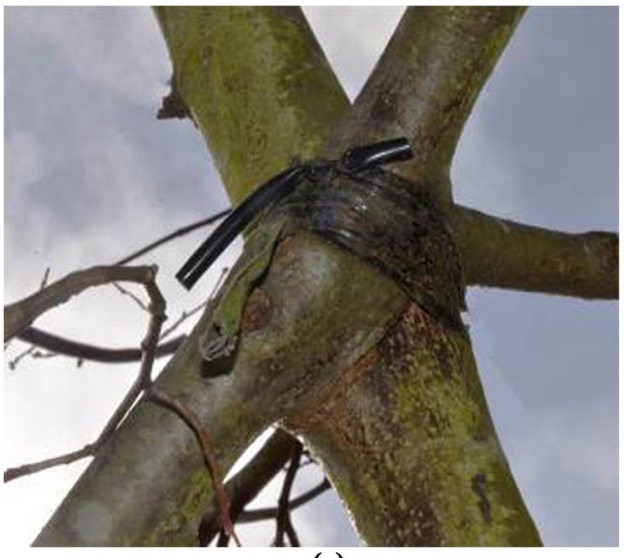

(a)

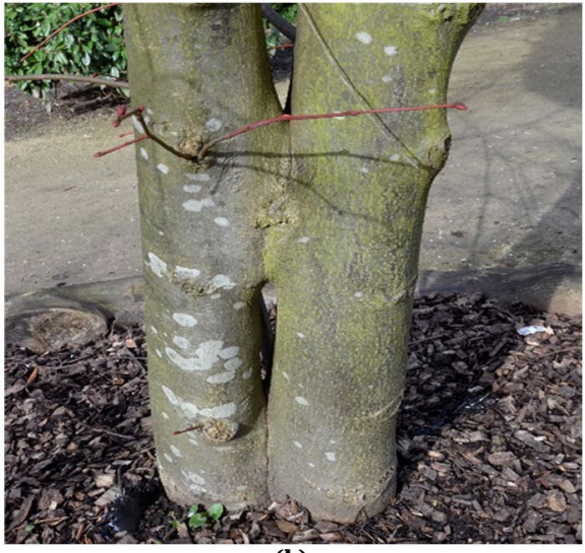

(b) 
Fig. 8 Typical self-growing connections for interconnected trees: three natural types are studied: (1) parallel-surface, (2) crosswise and (3) parallel-pith (Nuijten 2011)
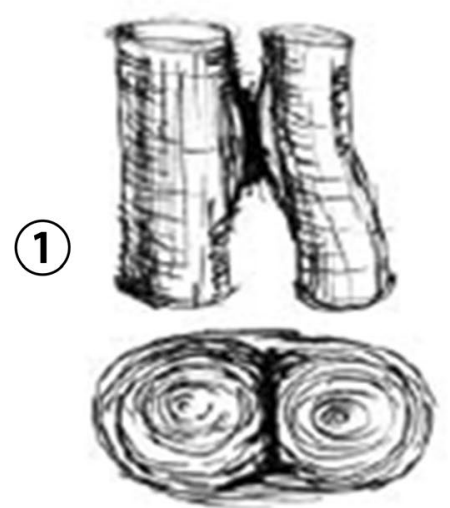

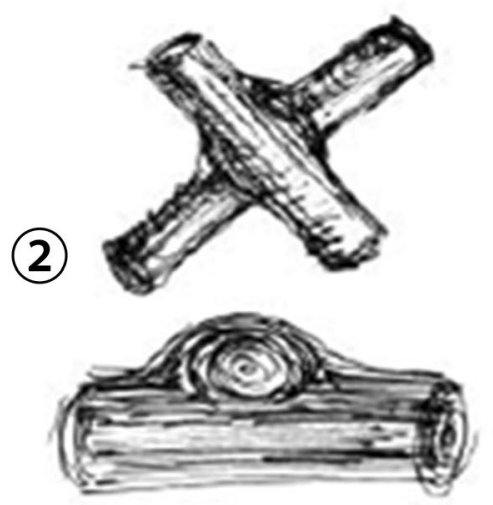

(3)

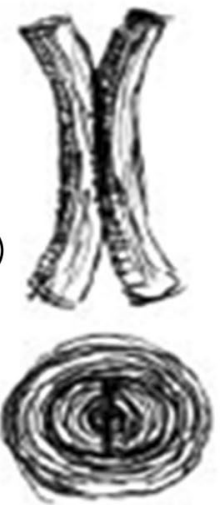

natural tree structures that ensure the stability of a structural tree network.

Three different self-growing connection types are identified as shown in Fig. 8. Each branch will probably retain its own biological and physiological features. Mechanical strength and stiffness will develop between trees to ensure the stability of the self-growing structure. The structure is the starting point to get a better understanding of the biological growth of the connections and structural performance of both trees and nodes. This future development of such structure may be used in the built environment, urban forests and vertical forests in particular (Borská 2018).

When this natural mechanical fixation system with selfgrowing connections is used in vertical forests, the anchoring of single trees to balconies can be reduced or become superfluous. The advantages envisaged for a vertical forest are a reduced need of fixing the trees to the main structure, but also reducing the effect of high wind loads on the shape of the individual trees. Consequently, excessive tree deformations will be reduced or can even be avoided completely. By using self-growing connections within vertical forests, the trees will be stabilized by neighboring trees, creating a more robust network on the outside of the building, while showing sufficient flexibility in high wind conditions. The trees will grow more naturally shaped, effectively making the vertical forest more appealing.

\subsection{Preliminary research}

The self-growing structure (Fig. 6) consists of several supports with self-growing connections. To find out the influence of connections within pairs of trees, the trees with the self-growing connections have been tested by pulling test experiments in the Botanical Garden at TU Delft (Borská 2018). Pulling tests have been carried out in tangential and radial directions of the connections (Fig. 9b). Pulling
Fig. 9 a Sketch of tree A3 with the parallel-surface connection (unit: $\mathrm{mm}$ ), b pulling directions

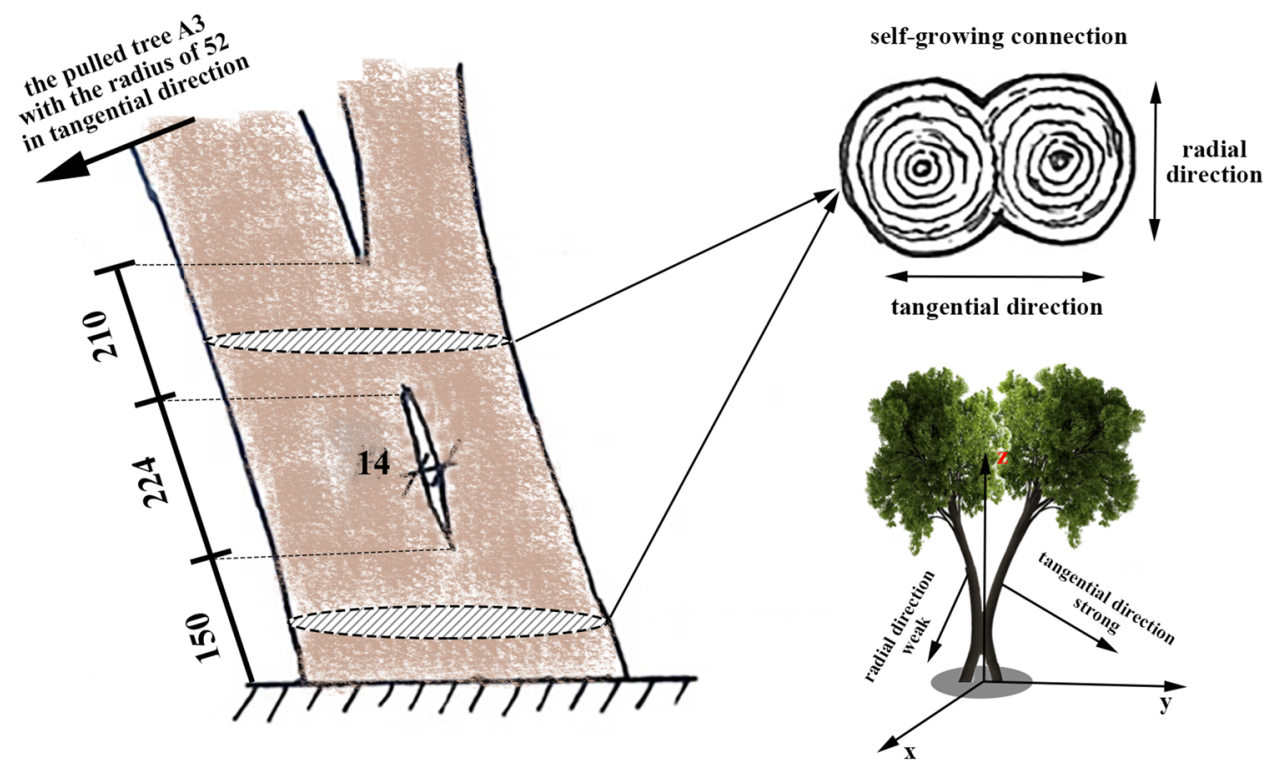

(a)

(b) 
force was applied through ropes with weights, and ropes were tied around tree stems with the length of the lever arm between 1 and $1.5 \mathrm{~m}$.

The characteristics of one of the supports are shown in Fig. 9, which includes the parallel-surface connection in Fig. 7b. As can be seen from Fig. 9, this support consists of two tree stems interconnected by two self-growing connections. Tree A is the tree which was pulled. If an individual tree is considered as a cantilevered beam, the deflection of this tree under a certain force can be calculated by Eq. (1). To show the influence of self-growing connections, an imaginary tree B is introduced. Tree B has the same mechanical properties and characteristics as tree A. The deflection of tree B can be calculated at the same force of tree A:

$\delta=\frac{F L^{3}}{3 E I}$

where $\delta(\mathrm{mm})$ is the deflection of tree B with a the length of level arm $L(\mathrm{~mm})$ from the pulling point to the base of tree B. $F(\mathrm{~N})$ is the force used for pulling test of tree A. $E(\mathrm{MPa})$ is the modulus of elasticity and is obtained from pulling tests. $I\left(\mathrm{~mm}^{4}\right)$ is the moment of inertia. Equation (1) is a simplified approach, as the total deflection is governed by rotational root stiffness and the bending stiffness of the tree structure. Thus, the bending stiffness in Eq. (1) shall be calculated as an equivalently effective bending stiffness covering the combined effect.
By comparing the deflections of tree A and tree $\mathrm{B}$, the contribution of self-growing connections can be represented by the ratio of deflections in two situations (tangential and radial). The preliminary results are listed in Table 4.

From the results in Table 4, it can be seen that tree A with self-growing connections has less deflection than tree $\mathrm{B}$ in two directions, indicating that the self-growing connections positively contribute to the stiffness of the tree network system. By this, the deflection of a single tree caused by external loads will be reduced. The wide scatter of stiffness ratio values between different supports is acknowledged and is attributed to i. a. the accuracy in the testing procedure, unknown and scatter in stiffness values of the individual components, such as non-constant cross sections in the trees and connection shapes, but also different root systems in the soil. These effects are still under study. Apart from this, the living conditions, the diameters of the trees and the age of connections also have an impact on the results. These will also influence the behavior in the future due to continuous growth.

\section{Conclusion}

- Classification and identification of green infrastructures Six types of vertical and horizontal greenery have been identified and classified in this study. Particularly, when trees are integrated vertically into high-rise buildings

Table 4 Comparison of results between pairs of trees

\begin{tabular}{|c|c|c|c|c|c|c|c|}
\hline Direction & $\begin{array}{l}\text { Name (A } \\
\text { tested; B calcu- } \\
\text { lated) }\end{array}$ & Force $\mathrm{F}(\mathrm{N})$ & $\begin{array}{l}\text { Modulus of } \\
\text { elasticity E } \\
(\mathrm{MPa})\end{array}$ & Radius (mm) & $\begin{array}{l}\text { Deflec- } \\
\text { tion } \delta \\
(\mathrm{mm})\end{array}$ & $\begin{array}{l}\text { Ratio between deflec- } \\
\text { tions of tree B and A }\end{array}$ & Type of connections (Fig. 8) \\
\hline \multirow[t]{2}{*}{ Radial } & Tree A1 & 235 & 20,439 & 23 & 5 & 23.8 & Parallel-surface and crosswise \\
\hline & Tree B1 & & & & 119 & & \\
\hline \multirow[t]{2}{*}{ Tangential } & Tree A1 & 353 & & & 3 & 33 & \\
\hline & Tree B1 & & & & 99 & & \\
\hline \multirow[t]{2}{*}{ Radial } & Tree A2 & 118 & 20,439 & 20 & 48 & 2.3 & Parallel-surface \\
\hline & Tree B2 & & & & 102 & & \\
\hline \multirow[t]{2}{*}{ Tangential } & Tree A2 & & & & 24 & 4.3 & \\
\hline & Tree B2 & & & & 102 & & \\
\hline \multirow[t]{2}{*}{ Radial } & Tree A3 & 353 & 13,165 & 52 & 8 & 1.1 & Parallel-surface \\
\hline & Tree B3 & & & & 9 & & \\
\hline \multirow[t]{2}{*}{ Tangential } & Tree A3 & & & & 2 & 4.5 & \\
\hline & Tree B3 & & & & 9 & & \\
\hline \multirow[t]{2}{*}{ Radial } & Tree A4 & 196 & 20,439 & 20 & 20 & 5 & Crosswise \\
\hline & Tree B4 & & & & 99 & & \\
\hline \multirow[t]{2}{*}{ Tangential } & Tree A4 & 235 & & & 2 & 107 & \\
\hline & Tree B4 & & & & 214 & & \\
\hline
\end{tabular}


using cantilevering balconies, this group of trees forms a vertical forest.

- Vertical forest and natural mechanical fixation systems

An application concept of natural mechanical fixation system to the vertical forest is introduced to ensure the stability of trees in containers and along the façade of a building. The fixation system allows for load transfer between tree both in horizontal and vertical directions. The preliminary results show that self-growing connections clearly contribute to the stiffness of a tree network system. This natural fixation manner may replace parts of artificial measures in a vertical forest system in the future. The mechanical properties of self-growing connections require further analyses to understand how their mechanical properties develop over time. The properties will increase with the growth of the trees, but the selfweight and external loads will also rise with increasing tree size.

- Planting strategies

There is still a lack of knowledge of how to deploy tall growing plants such as trees along high-rise building facades. From a botanical viewpoint, plant selection and planting strategies should be done with care, relating to the naturally available species in the region, but also with respect to the physiology and the root system. Considering plant characteristics and environmental conditions, a recommendation on planting strategies is presented for future development of vertical forest systems.

- Design considerations for VFE

For VFE, it is essential that design guidelines are developed including practical guidance for multi-criteria analyses. To design a vertical forest successfully, it is recommended to have a suitable planting strategy based on local climate and plant characteristics, to apply a natural mechanical fixation system and to consider both the structural and energy performance of buildings. Because the vertical forest is a dynamic growing system, it is necessary to introduce long term monitoring processes and reliability assessment tools with tree growth-time dependency. Part of the future work will focus on the natural mechanical fixation system regarding strength development and contribution to stability of vertical forests.

Acknowledgements We would like to thank the team from Botanical Garden of TU Delft for their valuable contributions to the implement.

Open Access This article is licensed under a Creative Commons Attribution 4.0 International License, which permits use, sharing, adaptation, distribution and reproduction in any medium or format, as long as you give appropriate credit to the original author(s) and the source, provide a link to the Creative Commons licence, and indicate if changes were made. The images or other third party material in this article are included in the article's Creative Commons licence, unless indicated otherwise in a credit line to the material. If material is not included in the article's Creative Commons licence and your intended use is not permitted by statutory regulation or exceeds the permitted use, you will need to obtain permission directly from the copyright holder. To view a copy of this licence, visit http://creativecommons.org/licenses/by/4.0/.

\section{References}

Aly AM, Fossati F, Muggiasca S et al (2013) Wind loading on trees integrated with a building envelop. Wind Struct 17:069-085

Argentini T, Fossati FV, Muggiasca S (2010) The vertical forest: wind loads on trees, pedestrian comfort, and net pressure distributions on facades. In: 9th UK Conference on Wind Engineering WES-2010, pp 1-4

Bartesaghi Koc C, Osmond P, Peters A (2017) Towards a comprehensive green infrastructure typology: a systematic review of approaches, methods and typologies. Urban Ecosyst 20:15-35. https://doi.org/10.1007/s11252-016-0578-5

Besir AB, Cuce E (2018) Green roofs and facades: a comprehensive review. Renew Sustain Energy Rev 82:915-939. https://doi. org/10.1016/j.rser.2017.09.106

Blanc P, Vr L (2008) The vertical garden: from nature to the city. W.W. Norton, New York

Borská H (2018) Structural performance of the self growing structure in the TU Delft Botanical Garden. Delft University of Technology, Delft

Coma J, Pérez G, de Gracia A, Burés S, Urrestarazu M, Cabeza LF (2017) Vertical greenery systems for energy savings in buildings: a comparative study between green walls and green facades. Build Environ 111:228-237. https://doi.org/10.1016/j. buildenv.2016.11.014

Cuce E (2017) Thermal regulation impact of green walls: an experimental and numerical investigation. Appl Energy 194:247-254. https://doi.org/10.1016/j.apenergy.2016.09.079

Dahanayake K, Chow C (2015) A brief discussion on current vertical greenery systems in Hong Kong: the way forward. In: 14th International conerence on sustainable energy technology (SET2015), 25-27 August 2015

Dunnett N, Kingsbury N (2008) Planting green roofs and living walls. Timber Press, Portland

Dupuy L, Fourcaud T, Stokes A (2007) A numerical investigation into the influence of soil type and root architecture on tree anchorage. Eco-and ground bio-engineering: the use of vegetation to improve slope stability. Springer, New York, pp 175-189

Feng H, Hewage K (2014) Lifecycle assessment of living walls: air purification and energy performance. J Clean Produ 69:91-99. https://doi.org/10.1016/j.jclepro.2014.01.041

Fernández-Cañero R, Pérez Urrestarazu L, Perini K (2018) Vertical greening systems: classifications, plant species, substrates. In: Pérez G, Perini K (eds) Nature based strategies for urban and building sustainability. Butterworth-Heinemann, Oxford, pp 45-54. https://doi.org/10.1016/B978-0-12-812150-4.00004-5

Francis RA, Lorimer J (2011) Urban reconciliation ecology: the potential of living roofs and walls. J Environ Manag 92:14291437. https://doi.org/10.1016/j.jenvman.2011.01.012

Giacomello E (2015) Case study: a new urban forest rises in Milan. Bosco Verticale, Milan

Herrero-Huerta M, Lindenbergh R, Gard W (2018) Leaf movements of indoor plants monitored by terrestrial LiDAR. Front Plant Sci. https://doi.org/10.3389/fpls.2018.00189

Hoyano A (1988) Climatological uses of plants for solar control and the effects on the thermal environment of a building. Energy 
Build 11:181-199. https://doi.org/10.1016/0378-7788(88)90035 $-7$

Ip K, Lam M, Miller A (2010) Shading performance of a vertical deciduous climbing plant canopy. Build Environ 45:81-88. https ://doi.org/10.1016/j.buildenv.2009.05.003

Koc CB, Osmond P, Peters A (2017) Towards a comprehensive green infrastructure typology: a systematic review of approaches, methods and typologies. Urban Ecosyst 20:11

Köhler M (2008) Green facades-a view back and some visions. Urban Ecosyst 11:423

Langre D (2008) Effects of wind on plants. Annu Rev Fluid Mech 40(141): 168. https://doi.org/10.1146/annurev.fluid.40.11140 6.102135

Marugg C (2018) Vertical forests: the impact of green balconies on the microclimate by solar shading, evapotranspiration and wind flow change. Delft University of Technology, Delft

Mazzali U, Peron F, Romagnoni P, Pulselli RM, Bastianoni S (2013) Experimental investigation on the energy performance of living walls in a temperate climate. Build Environ 64:57-66. https://doi. org/10.1016/j.buildenv.2013.03.005

McPherson EG, Herrington LP, Heisler GM (1988) Impacts of vegetation on residential heating and cooling. Energy Build 12:41-51. https://doi.org/10.1016/0378-7788(88)90054-0

Medl A, Stangl R, Florineth F (2017) Vertical greening systems: a review on recent technologies and research advancement. Build Environ 125:227-239. https://doi.org/10.1016/j.build env.2017.08.054

Moore J, Gardiner B, Sellier D (2018) Tree mechanics and wind loading. In: Geitmann A, Gril J (eds) Plant biomechanics. Springer, Cham. https://doi.org/10.1007/978-3-319-79099-2_4

Nelson P, Larkin D, Rocheleau P (1994) Treehouses: the art and craft of living out on a limb. Houghton Mifflin, Boston

Niklas KJ, Spatz H-C (2012) Plant physics. University of Chicago Press, Chicago

Nuijten A (2011) Living tree buildings. Delft University of Technology

Oberndorfer E, Lundholm J, Bass B et al (2007) Green roofs as urban ecosystems: ecological structures. Funct Serv BioSci 57:823-833. https://doi.org/10.1641/B571005

Ottelé M (2011) The green building envelope: vertical greening. Doctoral thesis, TU Delft

Pan L, Chu L (2016) Energy saving potential and life cycle environmental impacts of a vertical greenery system in Hong Kong: a case study. Build Environ 96:293-300

Peck SW, Callaghan C, Kuhn ME, Bass B (1999) Greenbacks from green roofs: forging a new industry in Canada. Citeseer, Ottawa

Pérez G, Coma J, Martorell I, Cabeza LF (2014) Vertical greenery systems (VGS) for energy saving in buildings: a review. Renew Sustain Energy Rev 39:139-165. https://doi.org/10.1016/j. rser.2014.07.055

Pérez-Urrestarazu L, Fernández-Cañero R, Franco-Salas A, Egea G (2015a) Vertical greening systems and sustainable cities. J Urban Technol 22:65-85

Pérez-Urrestarazu L, Fernández-Cañero R, Franco-Salas A, Egea G (2015b) Vertical greening systems and sustainable cities. J Urban Technol 22:65-85. https://doi.org/10.1080/10630732.2015.10739 00

Perini K, Ottelé M, Fraaij ALA, Haas EM, Rahim AM (2011) Vertical greening systems and the effect on air flow and temperature on the building envelope. Build Environ 46:2287-2294. https://doi. org/10.1016/j.buildenv.2011.05.009

Perini K, Ottelé M, Haas E, Raiteri R (2013) Vertical greening systems, a process tree for green façades and living walls. Urban Ecosyst $16: 265-277$

Perini K, Ottelé M, Giulini S, Magliocco A, Roccotiello E (2017) Quantification of fine dust deposition on different plant species in a vertical greening system. Ecol Eng 100:268-276. https://doi. org/10.1016/j.ecoleng.2016.12.032

Raji B, Tenpierik MJ, van den Dobbelsteen A (2015) The impact of greening systems on building energy performance: a literature review. Renew Sustain Energy Rev 45:610-623. https://doi. org/10.1016/j.rser.2015.02.011

Serra V, Bianco L, Candelari E et al (2017) A novel vertical greenery module system for building envelopes: the results and outcomes of a multidisciplinary research project. Energy Build 146:333-352. https://doi.org/10.1016/j.enbuild.2017.04.046

Sheweka S, Magdy AN (2011) The living walls as an approach for a healthy urban environment. Energy Proced 6:592-599. https://doi. org/10.1016/j.egypro.2011.05.068

Stec WJ, van Paassen AHC, Maziarz A (2005) Modelling the double skin façade with plants. Energy Build 37:419-427. https://doi. org/10.1016/j.enbuild.2004.08.008

Susorova I, Angulo M, Bahrami P, Brent S (2013) A model of vegetated exterior facades for evaluation of wall thermal performance. Build Environ 67:1-13. https://doi.org/10.1016/j.buildenv.2013.04.027

Susorova I, Azimi P, Stephens B (2014) The effects of climbing vegetation on the local microclimate, thermal performance, and air infiltration of four building facade orientations. Build Environ 76:113-124. https://doi.org/10.1016/j.buildenv.2014.03.011

Takakura T, Kitade S, Goto E (2000) Cooling effect of greenery cover over a building. Energy Build 31:1-6. https://doi.org/10.1016/ S0378-7788(98)00063-2

Tan PY, Köhler M, Peck S, Velazquez L, Urban Redevelopment A, National Parks B (2014) Vertical garden city: Singapore. Straits Times Press, Singapore

Tian Y, Jim CY (2011) Factors influencing the spatial pattern of sky gardens in the compact city of Hong Kong. Landsc Urban Plan 101:299-309. https://doi.org/10.1016/j.landurbplan.2011.02.035

Timur ÖB, Karaca E (2013) Vertical gardens. Advances in landscape architecture. IntechOpen, London

Tzoulas K, Korpela K, Venn S, Yli-Pelkonen V, Kaźmierczak A, Niemela J, James P (2007) Promoting ecosystem and human health in urban areas using green infrastructure: a literature review. Landsc Urban Plan 81:167-178. https://doi.org/10.1016/j.landu rbplan.2007.02.001

Wang C, Er S-S, Abdul-Rahman H (2016) Indoor vertical greenery system in urban tropics. Indoor Built Environ 25:340-356

Wilmers F (1990) Effects of vegetation on urban climate and buildings. Energy Build 15:507-514. https://doi.org/10.1016/03787788(90)90028-H

Wolverton B, Wolverton JD (1993) Plants and soil microorganisms: removal of formaldehyde, xylene, and ammonia from the indoor environment. J Miss Acad Sci 38:11-15

Wong NH, Tan AYK, Tan PY, Wong NC (2009) Energy simulation of vertical greenery systems. Energy Build 41:1401-1408. https:// doi.org/10.1016/j.enbuild.2009.08.010

Wong NH, Kwang Tan AY, Chen Y et al (2010a) Thermal evaluation of vertical greenery systems for building walls. Build Environ 45:663-672. https://doi.org/10.1016/j.buildenv.2009.08.005

Wong NH, Kwang Tan AY, Tan PY, Chiang K, Wong NC (2010b) Acoustics evaluation of vertical greenery systems for building walls. Build Environ 45:411-420. https://doi.org/10.1016/j.build env.2009.06.017

Wood A (2008) Trends and challenges in high-rise buildings in the 21st century. Chicago University Press, Chicago

Wood A, Bahrami P, Sfarik D (2014) Green wall in high-rise buildings: an output of the CTBUH sustainability. Council on Tall Buildings and Buban Habitat, Chicago

Xing Q, Hao X, Lin Y, Tan H, Yang K (2019) Experimental investigation on the thermal performance of a vertical greening system with green roof in wet and cold climates during 
winter. Energy Build 183:105-117. https://doi.org/10.1016/j. enbuild.2018.10.038

Yok TP (2013) Vertical garden city: Singapore. Straits Times Press, Singapore
Publisher's Note Springer Nature remains neutral with regard to jurisdictional claims in published maps and institutional affiliations. 